Installation Restoration Research Program

\title{
Adsorption and Transformation of RDX in Low-Carbon Aquifer Soils
}

Cynthia B. Price, James M. Brannon, Sally L. Yost, and Charolett A. Hayes 
The contents of this report are not to be used for advertising, publication, or promotional purposes. Citation of trade names does not constitute an official endorsement or approval of the use of such commercial products.

The findings of this report are not to be construed as an official Department of the Army position, unless so designated by other authorized documents. 


\section{Adsorption and Transformation of RDX in Low-Carbon Aquifer Soils}

by Cynthia B. Price, James M. Brannon

Environmental Laboratory

U.S. Army Engineer Research and Development Center 3909 Halls Ferry Road

Vicksburg, MS 39180-6199

Sally L. Yost, Charolett A. Hayes

DynTel Corporation

3530 Manor Drive, Suite 4

Vicksburg, MS 39180

Final report

Approved for public release; distribution is unlimited 


\section{Contents}

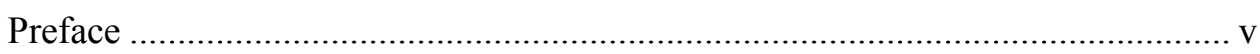

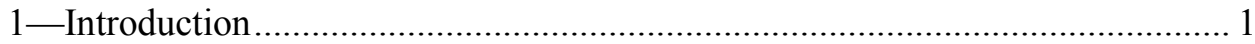

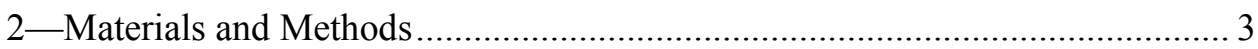

Soil Preparation

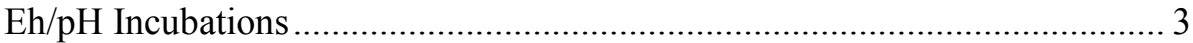

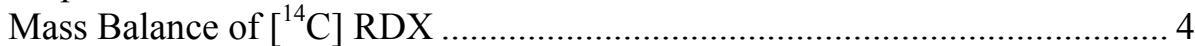

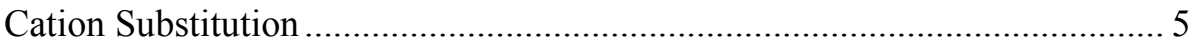

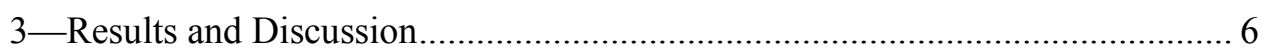

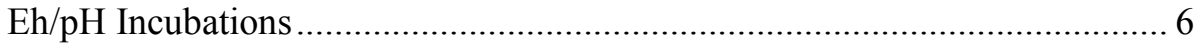

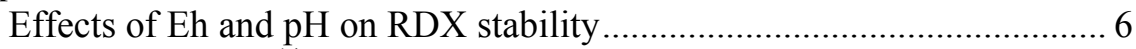

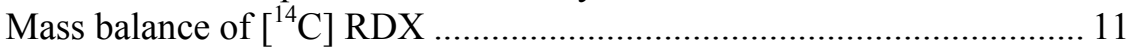

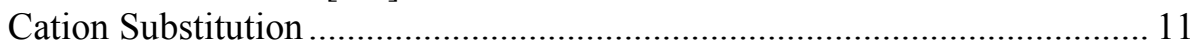

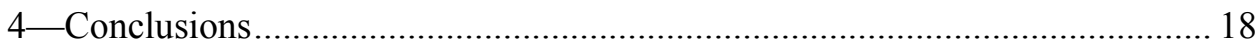

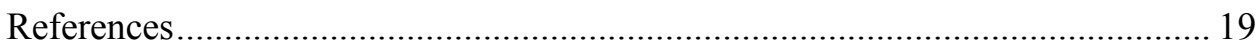

SF 298

\section{List of Figures}

Figure 1. System used to control Eh and $\mathrm{pH}$ over time ............................ 4

Figure 2. $\quad$ RDX aqueous concentrations over time at each Eh and $\mathrm{pH}$

Figure 3. RDX soil and aqueous concentrations 21 days after

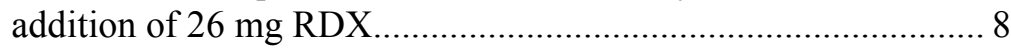

Figure 4. Percent recoveries of radioactivity in tests conducted with an uninoculated and inoculated aquifer soil and a surface soil 
Figure 5. Total mass of RDX remaining after incubation at each Eh and $\mathrm{pH}$...

Figure 6. RDX transformation products in solution over time at

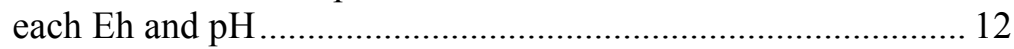

Figure 7. MNX aqueous concentrations over time at each Eh and

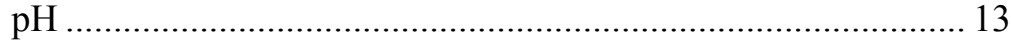

Figure 8. $\quad \mathrm{RDX}$ and its transformation products in solution over time at each $\mathrm{pH}$ and under highly reduced conditions.

Figure 9. Change in relative TNT concentrations as a function of $\mathrm{K}^{+}$and $\mathrm{Ca}^{++}$solution concentrations ........................................ 16

Figure 10. Adsorption of TNT to bi-ionic $\mathrm{K}^{+}: \mathrm{Ca}^{++}$, and homo-ionic $\mathrm{K}^{+}$and $\mathrm{Ca}^{++}$aquifer soil ................................................... 16 


\section{Preface}

The studies reported herein were conducted by the Environmental Laboratory (EL) of the U.S. Army Engineer Research and Development Center (ERDC), Vicksburg, MS. The research was conducted as part of the Installation Restoration Research Program (IRRP) and the Environmental Quality Basic Research Program. Dr. M. John Cullinane, EL, was the Program Manager. Dr. Clem Meyer was the IRRP Coordinator at the Directorate of Research and Development, Headquarters, U.S. Army Corps of Engineers.

Personnel who cooperated in the execution of the study and preparation of this report included Ms. Cynthia B. Price and Dr. James M. Brannon, Ecosystem Processes and Effects Branch, Environmental Processes and Effects Division (EPED), EL; and Ms. Sally L. Yost and Ms. Charolett A. Hayes, DynTel Corporation, Vicksburg, MS. Technical reviews were provided by Dr. Judith C. Pennington, EPED, and Dr. Patrick Deliman, Water Quality and Contaminant Modeling Branch, EPED.

The study was conducted under the direct supervision of Dr. Richard E. Price, Chief, EPED, and under the general supervision of Dr. Edwin A. Theriot, Acting Director, EL.

At the time of publication of this report, Director of ERDC was Dr. James R. Houston. Commander and Executive Director was COL John W. Morris III, EN.

This report should be cited as follows:

Price, C. B., Brannon, J. M., Yost, S. L., and Hayes, C. A. (2001). "Adsorption and transformation of RDX in a low-carbon aquifer soil,” ERDC/EL TR-01-19, U.S. Army Engineer Research and Development Center, Vicksburg, MS.

The contents of this report are not to be used for advertising, publication, or promotional purposes. Citation of trade names does not constitute an official endorsement or approval of the use of such commercial products. 


\section{Introduction}

The explosives 2,4,6-trinitrotoluene (TNT), hexahydro-1,3,5,-trinitro-1,3,5triazine (RDX), and octahydro-1,3,5,7-tetranitro-1,3,5,7-tetrazocine (HMX) have been widely used in manufacturing, loading, assembling, and packaging munitions for many decades in the United States. Disposal processes from these operations resulted in contamination at many active and inactive munitions sites (Pugh 1982, Spaulding and Fulton 1988), leading to migration of these compounds into groundwater (Cattaneo et al. 2000). The rate of movement in an aquifer soil depends on the hydraulic properties of the aquifer and processes such as transformation and adsorption of the explosive. TNT is unstable under a wide range of environmental conditions, undergoing rapid transformation and binding by soil organic matter (Price, Brannon, and Hayes 1997). RDX and HMX may pose the more persistent groundwater problem because their mobility is not limited by sorption, degradation, and immobilization as is TNT and its degradation products (Pennington and Brannon, in press; Price et al. 2001). RDX plumes that are larger than the associated TNT plumes have been observed under sites heavily contaminated with both compounds (Spalding and Fulton 1988).

Results of microbial batch culture studies in wastewater and in media other than soils have shown that RDX is subject to transformation and mineralization under anaerobic conditions (Spanggord et al. 1980; McCormick, Cornell, and Kaplan 1984; Crawford 1995). Transformation of RDX to mono, di, and trinitroso derivatives under anaerobic conditions has been reported (Sikka et al. 1980; Spanggord et al. 1980; McCormick, Cornell, and Kaplan 1984; Crawford 1995). Resistance to aerobic degradation has also been reported (Spanggord et al. 1980; McCormick, Cornell, and Kaplan 1984). Studies conducted with soils have shown that transformation rather than sorption is a more important mechanism for removal of RDX, but the processes affecting transformation are not well understood (Myers et al. 1998). Surface soils have been shown to rapidly transform and sorb TNT and its transformation products under a wide range of redox potential (Eh) and pH conditions (Price, Brannon, and Hayes 1997; Price et al. 2001). Studies conducted with surface soils (typically comprised of 1 to 3 percent organic carbon) revealed that RDX was relatively stable in soil-water slurries under all but highly anaerobic conditions (Price et al. 2001). Results of adsorption tests in lowcarbon aquifer soils indicate that sorption and transformation of explosives are significantly lower than in surface soils (Pennington and Patrick 1990; Pennington et al. 1999). 
Surface soils have been shown to rapidly adsorb and transform TNT under a wide range of Eh and $\mathrm{pH}$ conditions (Price, Brannon, and Hayes 1997;

Pennington and Brannon, In Press). Specific adsorption to clay minerals can also be a significant process for nitroaromatics in which the magnitude of sorption is affected by the specific cation sorbed (Haderlein and Schwarzenbach 1993;

Haderlein, Weissmahr, and Schwarzenbach 1996; Weissmahr, Haderlein, and Schwarzenbach 1998; Weissmahr et al. 1999). Saturation of clay exchange sites

with $\mathrm{NH}_{4}^{+}, \mathrm{K}^{+}, \mathrm{Cs}^{+}$, and $\mathrm{Rb}^{+}$increases the adsorption of nitroaromatics (Haderlein and Schwarzenbach 1993) and explosives (Haderlein, Weissmahr, and Schwarzenbach 1996), while saturation with $\mathrm{Ca}^{++}$decreases adsorption (Haderlein, Weissmahr, and Schwarzenbach 1996). Although most of the work has been conducted with clay minerals, the potential for electrolyte injections in the field to control the mobility of 4-nitrotoluene has been demonstrated (Weissmahr et al. 1999).

Although nitroaromatics can undergo natural attenuation in aquifer soils, the processes governing the transformation of explosives in these soils are not well understood. Therefore, investigations are needed to understand the effects of physicochemical conditions on the sorption and transformation of RDX in soil/water slurry systems. Adsorption tests conducted with unmodified aquifer soils indicate that sorption and transformation of explosives are minimal in low carbon compared with surface soils (Pennington and Patrick 1990; Pennington et al. 1999). Understanding the effects of groundwater quality on the sorption of explosives is necessary to understand the mechanisms of natural attenuation in aquifer soils. The objective of the investigations described in this report was to determine the effects of Eh and $\mathrm{pH}$ on RDX sorption and transformation in a lowcarbon aquifer soil. Studies addressing the various degrees of cation substitution on adsorption of TNT in aquifer soils and on two clay minerals are also reported. 


\section{Materials and Methods}

\section{Soil Preparation}

An aquifer soil obtained from Louisiana Army Ammunition Plant (LAAP), Minden, LA, was used to investigate the effects of Eh and $\mathrm{pH}$ on the transformation of RDX. The aquifer soil was obtained by excavating approximately $3 \mathrm{cu} \mathrm{m}$ of soil 1.2 to $3 \mathrm{~m}$ ( 4 to $10 \mathrm{ft}$ ) below the ground surface. The soil was transported offsite, air-dried, sieved through a 3-mm mesh sieve, and homogenized in a cement mixer. Explosives analyses were performed using a modified (ultrasonic extraction) EPA SW-846 Method 8330 (U.S. Environmental Protection Agency (USEPA) 1994).

\section{Eh/pH Incubations}

Tests were conducted in 2,800-ml Fernbach flasks. Glucose was added as an energy source at a rate of $1 \mathrm{~g}$ every 4 days to maintain microbial removal of oxygen and other electron acceptors from the systems. Sufficient distilled deionized water was added to the flasks to produce a water-to-solids ratio of 18:1 (150 g oven dry weight soil in 2,600 ml water). The water-soil slurries were kept in suspension by magnetic stirring and were maintained at room temperature that averaged $24^{\circ} \mathrm{C} \pm 2$.

The Eh and $\mathrm{pH}$ in the slurries were maintained using the methods developed by Patrick, Williams, and Moraghan (1973) with some modifications (Brannon 1983). The Eh was monitored by platinum and $\mathrm{Ag}-\mathrm{AgCl}$ electrodes connected to a pH-millivolt meter (Beckman Instruments, Fullerton, CA). The desired Eh was set on a meter relay (Currier and Roser, New Orleans, LA), which by activating an aquarium pump to introduce air into the system when the set point was reached, prevented the Eh from falling below a preset value (Figure 1). To help maintain anaerobic conditions, nitrogen gas was flushed through the system at a rate of approximately $15 \mathrm{ml} / \mathrm{min}$. System $\mathrm{pH}$ was monitored using a combination $\mathrm{pH}$ electrode connected to a separate $\mathrm{pH}$-millivolt meter. A set slurry $\mathrm{pH}$ was maintained by injecting $1.0 \mathrm{~N} \mathrm{HCl}$ or $1.0 \mathrm{~N} \mathrm{NaOH}$ via a syringe through a serum cap. The soil suspensions were allowed to incubate and stabilize for approximately 3 weeks. The study consisted of triplicate tests at two Eh levels, +500 (oxidizing) and $-150 \mathrm{mV}$ (highly reduced), and three $\mathrm{pH}$ values, 6.0, 7,0, and 8.0. 


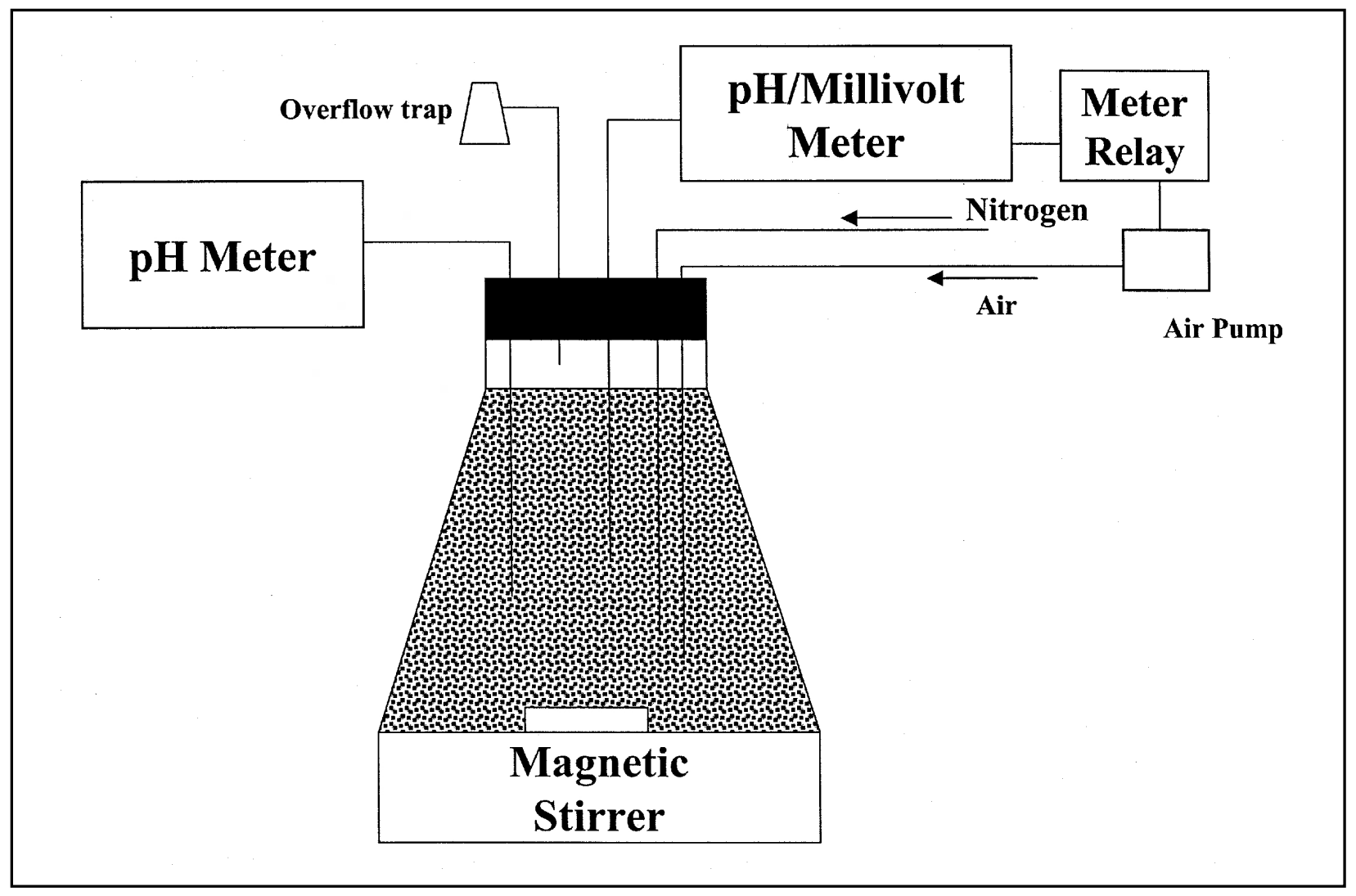

Figure 1. System used to control Eh and pH over time

Following stabilization of the Eh and $\mathrm{pH}$ in each reactor, $1 \mathrm{ml}$ of acetone containing $26 \mathrm{mg}$ RDX (equivalent to $10 \mathrm{mg} / \mathrm{L}$ ) was added to each flask. All flasks were covered with aluminum foil prior to spiking to prevent photodecomposition of the added compound. Slurry samples were withdrawn $24 \mathrm{hr}$ and 4,12 , and 21 days after addition of RDX, then centrifuged at 1000 relative centrifugal force (RCF) for $30 \mathrm{~min}$ to separate the aqueous phase. Aqueous phase was analyzed for RDX and its mono, di, and trinitroso transformation product derivative according to EPA SW-846 Method 8330 (USEPA 1994). Following 15 days incubation, the soils and waters were separated via centrifugation, and soils were analyzed for the same parameters as the waters (USEPA 1994).

\section{Mass Balance of $\left[{ }^{14} \mathrm{C}\right] \mathrm{RDX}$}

Mass balance of RDX was determined using uniformly ring-labeled $\left[{ }^{14} \mathrm{C}\right]$ RDX with a specific activity of $4.3 \mathrm{mCi} / \mathrm{mmol}$ and radiochemical purity of 98.4 percent (New England Nuclear Research Products, Boston, MA). Tests were run in triplicate at +500 and $-150 \mathrm{mV}$ at $\mathrm{pH}$ 7. A bubble trap containing $1 \mathrm{~N} \mathrm{KOH}$ was attached to each flask to trap $\mathrm{CO}_{2}$. The total incubation period was 21 days. The water and $\mathrm{KOH}$ traps were sampled periodically throughout the incubation period. The soils were sampled on day 21 . Radioactivity in the aqueous phase and in the $\mathrm{CO}_{2}$ traps was determined by counting $1 \mathrm{ml}$ of water or $\mathrm{KOH}$ in $15 \mathrm{ml}$ Ultima Gold Liquid Scintillation Cocktail (Packard Instruments, Meridan, CT) on 
a Packard Tricarb 2500 TR Liquid Scintillation (LS) Counter (Packard Instruments, Meridan, CT). The soil was analyzed for radioactivity by complete combustion in a Model 307 Packard Sample Oxidizer (Packard Instruments, Meridan, CT). Radiolabeled $\mathrm{CO}_{2}$ was trapped in Carbo-Sorb and Permafluor Liquid Scintillation Cocktail (Packard Instruments, Meridan, CT) and assayed by LS.

A second test using $\left[{ }^{14} \mathrm{C}\right] \mathrm{RDX}$ was conducted to determine the effects of the addition of a surface soil to the aquifer soil on microbial activity in the reactors. The experiment was conducted in duplicate using an identical experimental design to that of the mass balance test described previously. Reactors were maintained at an Eh of $-150 \mathrm{mV}$ and a $\mathrm{pH}$ of 7 . Glucose was added as an energy source, and an additional $1 \mathrm{~g}$ of Yokena Clay (a surface soil used in previous experiments (Price et al. 2001)) was added. The tests were allowed to incubate for 4 weeks to stabilize the Eh and $\mathrm{pH}$ of the systems and to allow the added microbial community in the surface soil to stabilize. Sampling of the aqueous phase and $\mathrm{KOH}$ was conducted as previously described over a 3-week period, and the soils were sampled at the completion of the test.

\section{Cation Substitution}

Characteristics of the three aquifer soils from LAAP and two clays have been previously reported (Price et al. 2000). Methods of saturating the ion exchange complex with $\mathrm{K}^{+}$and $\mathrm{Ca}^{++}$and determining partitioning coefficients with TNT, RDX, and HMX have also been reported (Price et al. 2000). Therefore, only the methodologies involved in determining the effects of varying degrees of cation saturation on sorption of TNT are presented.

The effects of varying cation composition and degree of saturation on TNT sorption in LAAP C aquifer soil was evaluated in two ways. First, $4 \mathrm{~g}$ of aquifer soil was shaken for $24 \mathrm{hr}$ with $16 \mathrm{ml}$ of solution containing from 26.2 to $542 \mathrm{mg} / \mathrm{L}$ $\mathrm{K}^{+}$in $25-\mathrm{ml}$ glass centrifuge tubes. The mixture was centrifuged and the liquid decanted. A solution at the same $\mathrm{K}^{+}$concentration was spiked with $100 \mu \mathrm{L}$ of radiolabeled TNT and added to the soil. Tubes were shaken for an additional $24 \mathrm{hr}$. The mixture was centrifuged, decanted, and counted as previously described. This experiment was repeated with a mixed $\mathrm{K}^{+} / \mathrm{Ca}^{++}$solution containing from 19.7 to $393 \mathrm{mg} / \mathrm{L} \mathrm{K}^{+}$and from 6.5 to $130.7 \mathrm{mg} / \mathrm{L} \mathrm{Ca}^{++}$. The mixed solution maintained a constant $\mathrm{K}^{+} / \mathrm{Ca}^{++}$ratio of 3/1. Second, LAAP $\mathrm{C}$ aquifer soils at various levels of homo-ionic $\mathrm{K}^{+}$and $\mathrm{Ca}^{++}$saturation were obtained by mixing appropriate amounts of homo-ionic aquifer soil with unamended aquifer soil. $\mathrm{Bi}$-ionic $\mathrm{Ca}^{++} / \mathrm{K}^{+}$aquifer soil was obtained by mixing appropriate amounts of homo-ionic aquifer soils. Sufficient distilled deionized water was added to produce a 4:1 water:soil ratio, and the mixture was spiked with appropriate levels of radiolabeled TNT, shaken for $24 \mathrm{hr}$, centrifuged, and counted as previously described. Measured partition coefficients for $\mathrm{K}^{+}(6.5 \mathrm{~L} / \mathrm{kg})$ and $\mathrm{Ca}^{++}(20.2 \mathrm{~L} / \mathrm{kg})$ in aquifer soil were sufficiently high so that desorbed $\mathrm{K}^{+}$and $\mathrm{Ca}^{++}$would rapidly redistribute over the soil mass and not result in substantial alterations of the soil fraction occupied by either $\mathrm{K}^{+}$or $\mathrm{Ca}^{++}$. 


\section{Results and Discussion}

\section{$\mathrm{Eh} / \mathrm{pH}$ Incubations}

\section{Effects of Eh and pH on RDX stability}

RDX was relatively stable at all $\mathrm{pH}$ levels under aerobic conditions (Figure $2 \mathrm{a})$. Anaerobic conditions $(-150 \mathrm{mV})$ resulted in decreased aqueous concentrations over time, yet RDX never completely disappeared from solution (Figure $2 \mathrm{~b}$ ). Results of soil analysis revealed lower concentrations of RDX remaining in the soil in the $-150-\mathrm{mV}$ tests as compared with the $+500-\mathrm{mV}$ tests; however, RDX never completely disappeared from the soil or solution phase 21 days after addition of $26 \mathrm{mg}$ RDX (Figure 3a). Soil analysis results were consistent with results for the aqueous phase, in that the ratios of concentrations in oxidized-toreduced treatments were similar. Approximately 10:1 of the RDX was recovered from the aqueous phase. These results are similar to those seen in experiments conducted with a surface soil where approximately 8:1 of the RDX was recovered in the aqueous phase in both oxidized and reduced treatments (Price et al. 2001). $\mathrm{RDX}$ was more stable under anaerobic conditions in the aquifer soil than in the surface soil. RDX decreased to low levels in the surface soil with complete removal at $\mathrm{pH} 7$ at 15 days after addition of $26 \mathrm{mg}$ RDX. The lack of RDX removal was probably due to either microbial community or nutrient limitations in the aquifer soil. The addition of a $1 \mathrm{~g}$ surface soil inoculum to the aquifer soil prior to RDX addition gave results similar to those observed for uninoculated aquifer soil (Figure 4). These results indicate that the surface soil microbial community was not able to function in the aquifer soil even in the presence of a glucose energy source.

RDX removal (aqueous plus soil) from the slurries was observed at all $\mathrm{pH}$ levels under anaerobic conditions, with the highest removal at $\mathrm{pH} 6$ (Figure 5). To determine if varying $\mathrm{Eh} / \mathrm{pH}$ conditions affected RDX sorption, single-point distribution coefficients $\left(K_{d}\right)$ for each $\mathrm{Eh}$ and $\mathrm{pH}$ were calculated from aqueous and soil RDX concentrations on day 21:

$$
K_{d}=\frac{Q(t)}{C(t)}
$$




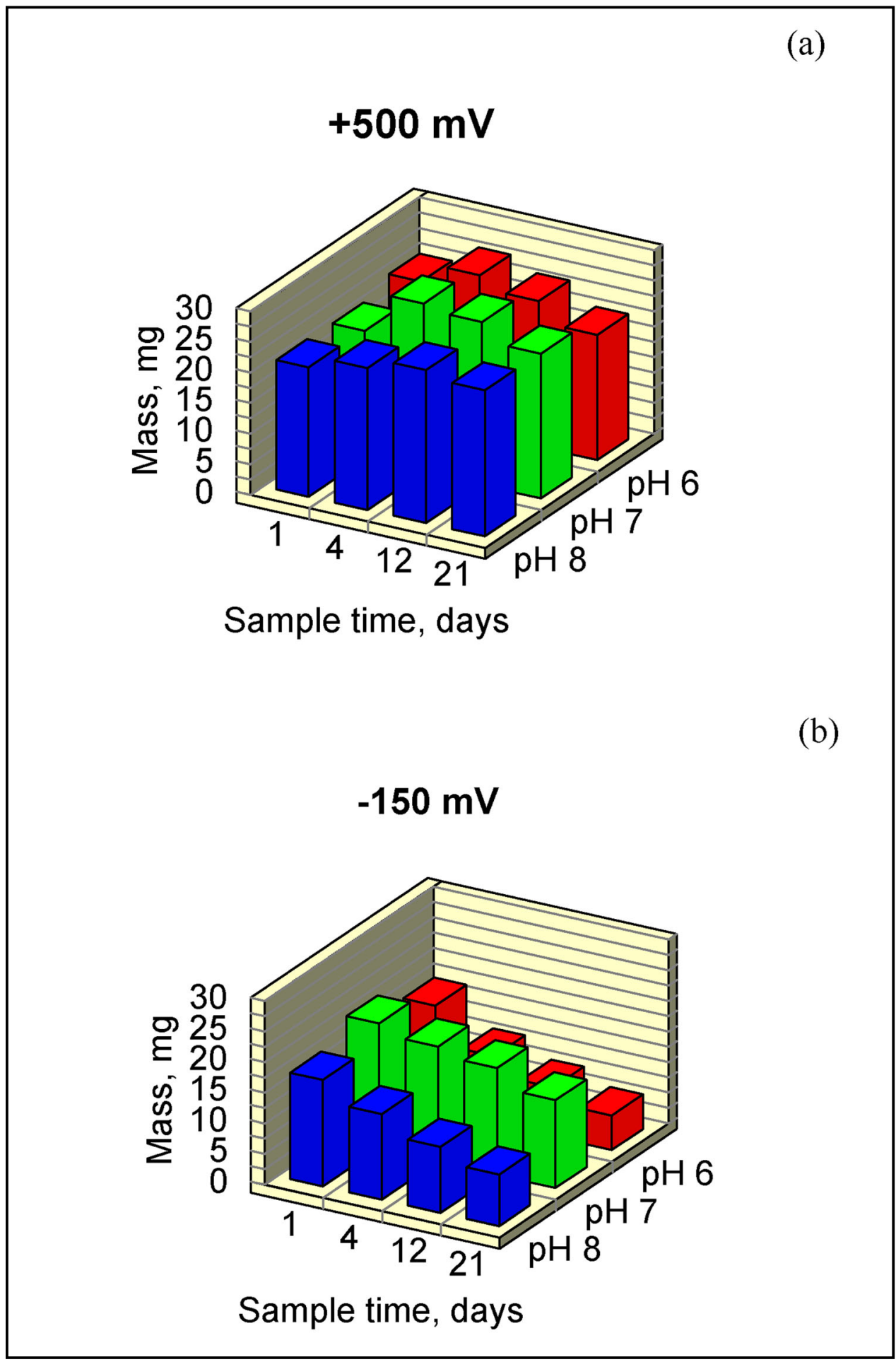

Figure 2. RDX aqueous concentrations over time at each Eh and $\mathrm{pH}$

where

$$
\begin{aligned}
& Q=\text { soil concentration }(\mathrm{mg} / \mathrm{kg}) \text { at sample time }(t) \\
& C=\text { aqueous concentration }(\mathrm{mg} / \mathrm{L}) \text { at sample time }(t)
\end{aligned}
$$




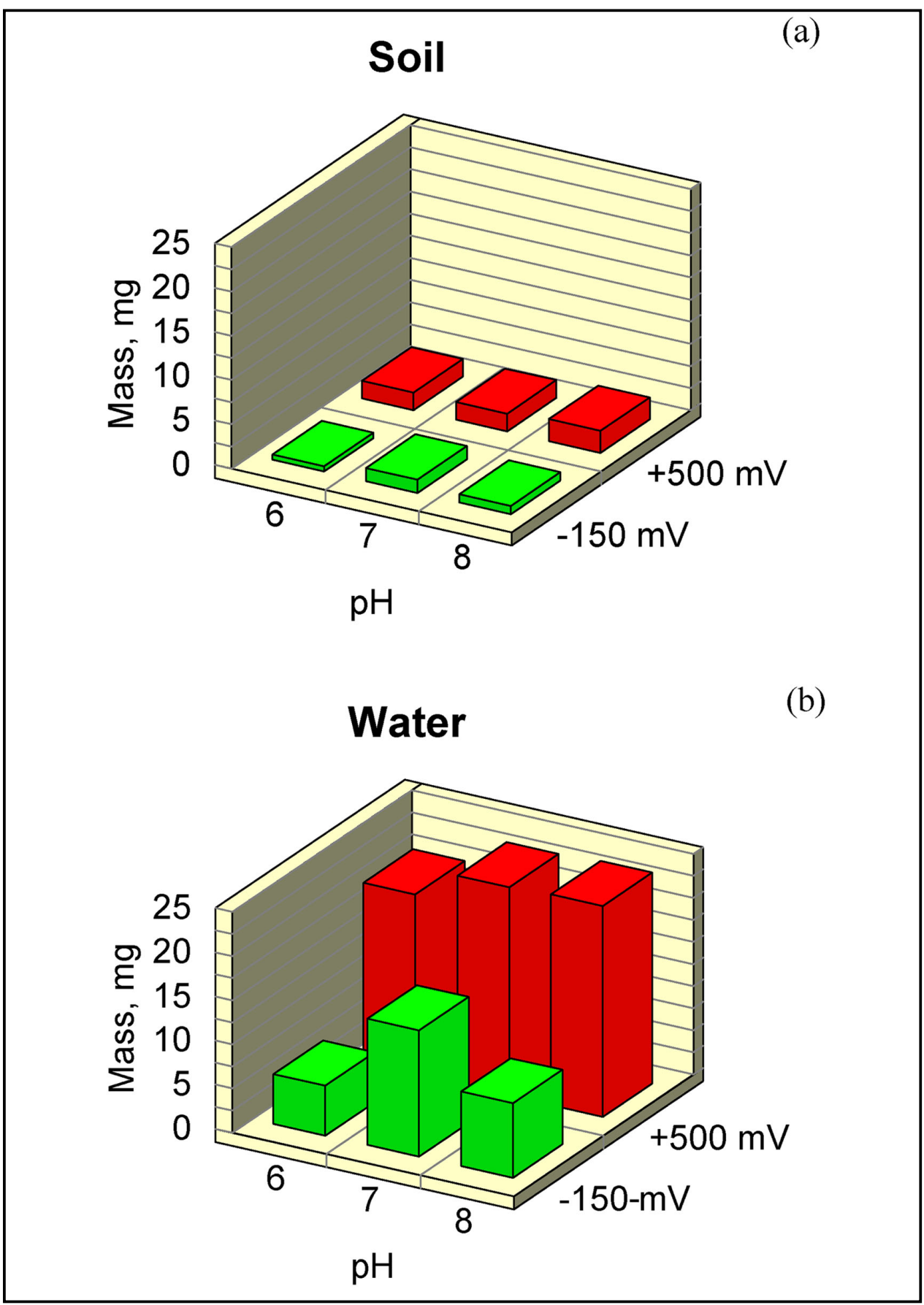

Figure 3. RDX soil and aqueous concentrations 21 days after addition of $26 \mathrm{mg}$ RDX

No consistent trend was noted for soil sorption under aerobic and anaerobic conditions (Table 1). Increased effects of $\mathrm{pH}$ on sorption were noted in the $-150-\mathrm{mV}$ tests where $\mathrm{pH} 7$ conditions promoted sorption. These results differ from those seen in studies conducted with a surface soil in which decreased soil sorption was noted for all $\mathrm{pH}$ conditions under anaerobic conditions (Price, Brannon, and Yost 1998). 


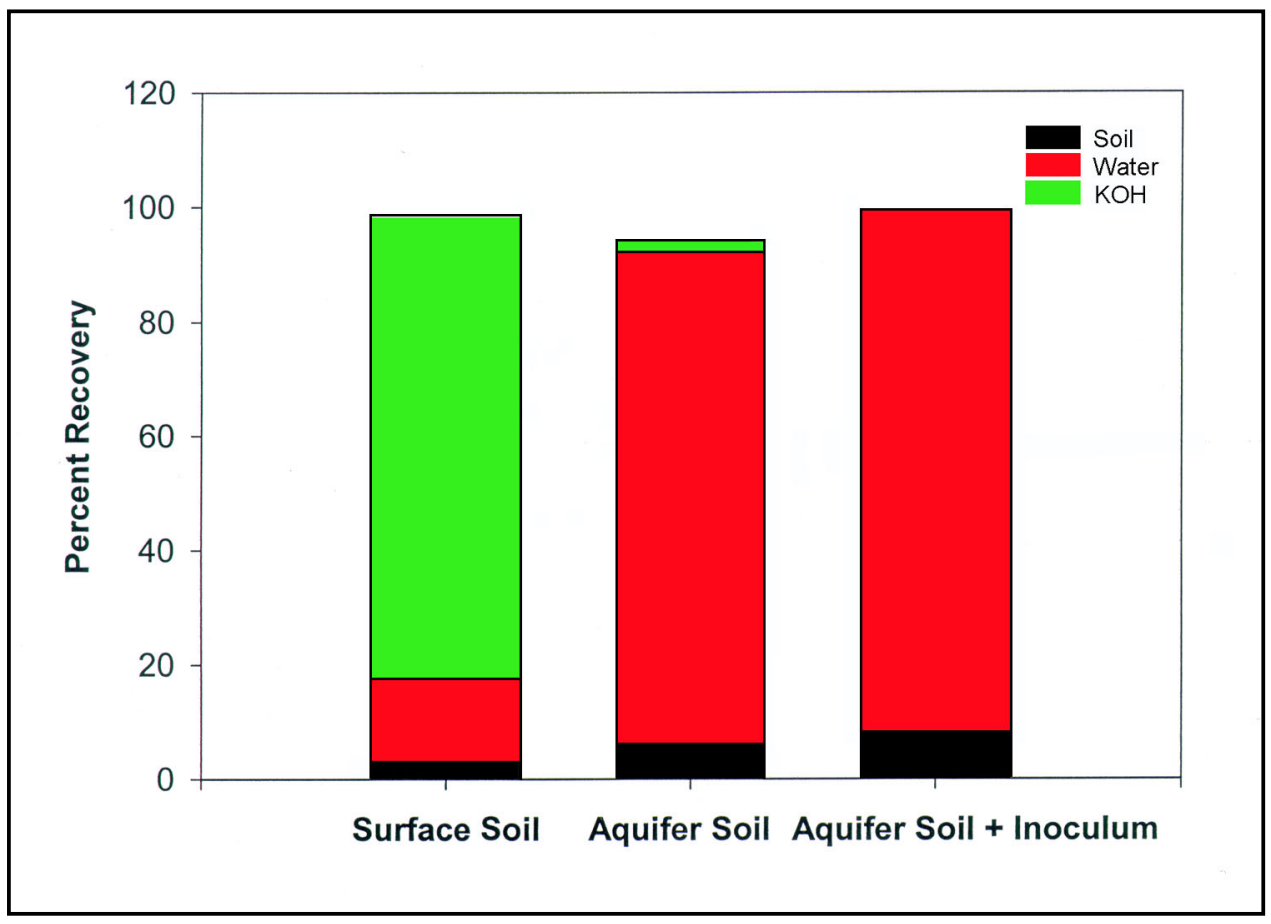

Figure 4. Percent recoveries of radioactivity in tests conducted with an uninoculated and inoculated aquifer soil and a surface soil

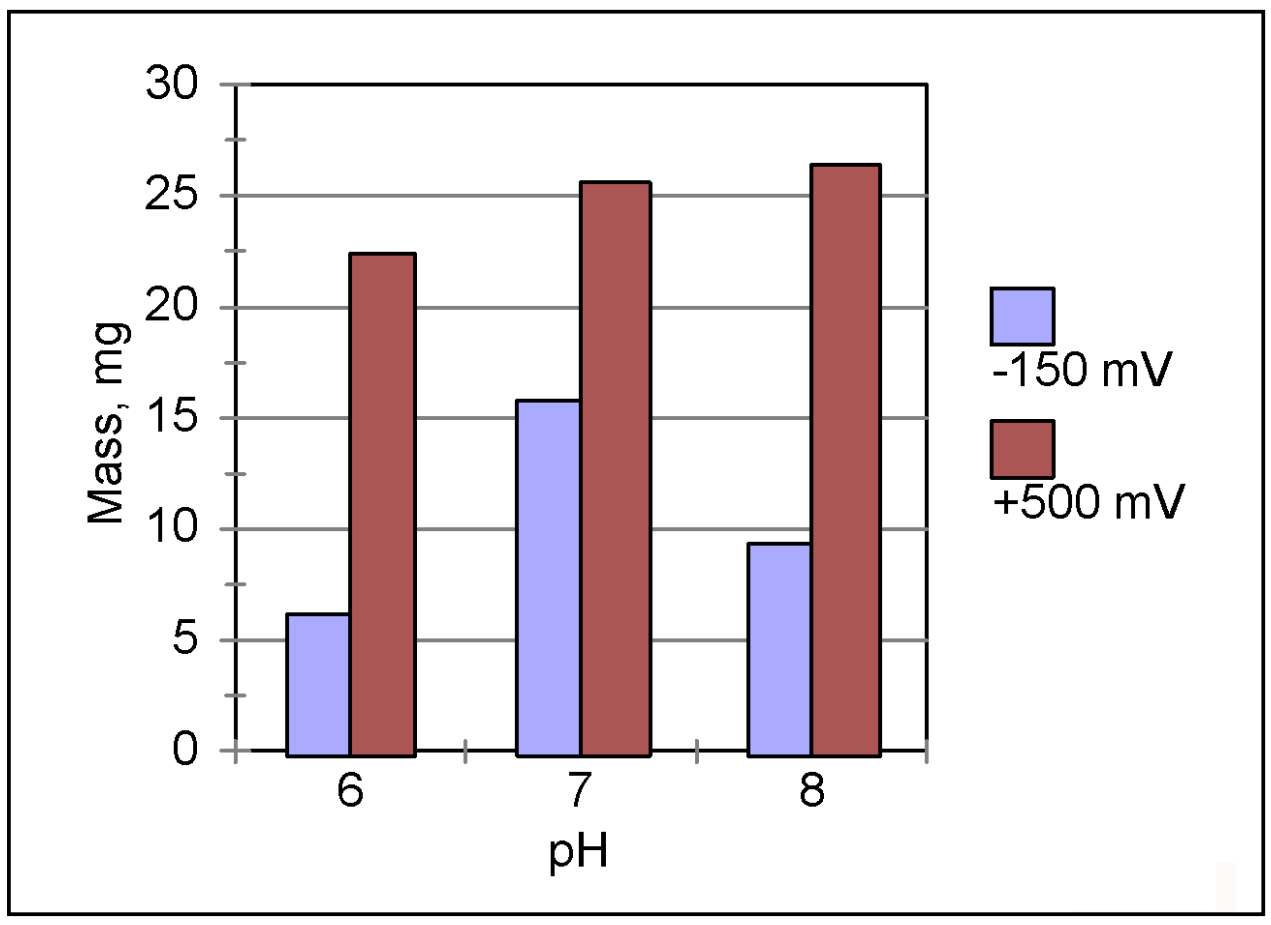

Figure 5. Total mass of RDX remaining after incubation at each Eh and $\mathrm{pH}$ 


\begin{tabular}{|c|c|c|}
\hline \multicolumn{3}{|c|}{$\begin{array}{l}\text { Table } 1 \\
\text { RDX Distribution Coefficients } K_{d}, \text { L/kg (standard error) } 21 \text { Days } \\
\text { After Addition of RDX }\end{array}$} \\
\hline$\overline{\mathrm{pH}}$ & +500 mV & 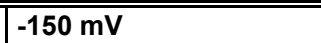 \\
\hline 6 & $5.81(0.65)$ & $1.94(0.95)$ \\
\hline 7 & $6.27(0.50)$ & $15.8(3.6)$ \\
\hline 8 & $4.89(0.47)$ & $4.12(0.45)$ \\
\hline
\end{tabular}

Processes that remove RDX from solution can be expressed with psuedo first-order kinetics which take the form

$$
\frac{d c}{d t}=-k c
$$

where

$$
\begin{aligned}
& c=\text { chemical concentration of reacting substance } \\
& k=\text { pseudo first-order reaction constant }
\end{aligned}
$$

First-order kinetics then reduce to the equation

$$
\ln \left(\frac{c_{0}}{c}\right)=k t
$$

where $c_{0}$ is the concentration of the reacting substance at time 0 . Once a value of $k$ is obtained, the half-life period of the reacting substance, $t_{1 / 2}$, can be calculated using the equation

$$
t_{1 / 2}=\frac{0.693}{k}
$$

\begin{tabular}{|c|c|c|c|}
\hline \multicolumn{4}{|c|}{$\begin{array}{l}\text { Table } 2 \\
\text { Regression Coefficient }\left(r^{2}\right) \text {, First-Order Rate Coefficient }(k) \text {, and Halt } \\
\text { Life }\left(t_{1 / 2}\right) \text { for RDX at Each Eh/pH Treatment }\end{array}$} \\
\hline $\mathrm{pH}$ & $r^{2}$ & $k, \mathrm{hr}^{-1}$ & $t_{1 / 2}, \mathrm{hr}$ \\
\hline \multicolumn{4}{|c|}{$-150 \mathrm{mV}$} \\
\hline 6 & 0.92 & \begin{tabular}{|l|}
0.0021 \\
\end{tabular} & 328 \\
\hline 7 & 0.98 & 0.0007 & 996 \\
\hline 8 & 0.96 & \begin{tabular}{|l|}
0.0014 \\
\end{tabular} & 485 \\
\hline \multicolumn{4}{|c|}{$+500 \mathrm{mV}$} \\
\hline 6 & 0.47 & NS & NS \\
\hline 7 & 0.02 & NS & $\mathrm{NS}$ \\
\hline 8 & 0.44 & NS & NS \\
\hline
\end{tabular}

To quantify the rates of disappearance, RDX concentrations were fit to the pseudo first-order kinetic equation. RDX removal from solution was more rapid at $-150 \mathrm{mV}$ than at $+500 \mathrm{mV}$, with the fastest removal occurring at $\mathrm{pH} 6$ and the slowest at pH 7 (Table 2). The half lives for RDX in these studies differed 
significantly from those in identical studies conducted with a surface soil where half lives for RDX were less than $6 \mathrm{hr}$ in the $-150-\mathrm{mV}$ tests as compared with a half life between 328 and $996 \mathrm{hr}$ in these investigations (Price et al. 2001).

RDX transformation product formation was rapid and related to the Eh of the system, with lower Eh conditions resulting in a greater number and concentration of products (Figure 6). The RDX transformation product, MNX, appeared in all treatments within $24 \mathrm{hr}$ following RDX addition. Aqueous concentrations generally increased over time in the $+500-\mathrm{mV}$ tests (Figure 7). By day 21, solution concentrations of MNX in the $+500-\mathrm{mV}$ tests ranged from $0.018 \mathrm{mg} / \mathrm{L}$ at $\mathrm{pH} 8$ to $0.086 \mathrm{mg} / \mathrm{L}$ at $\mathrm{pH} 7$. In the $-150-\mathrm{mV}$ tests, solution concentrations increased to day 11 of sampling in the $\mathrm{pH} 6$ treatments followed by a decrease in solution concentration to $0.84 \mathrm{mg} / \mathrm{L}$. In the $\mathrm{pH} 7$ and 8 tests, $\mathrm{MNX}$ aqueous concentrations increased to day 4 and remained relatively stable for the duration of the test. These results are similar to those seen in tests conducted with a surface soil, where MNX appeared in solution $24 \mathrm{hr}$ after additions of RDX (Price et al. 2001).

The disappearance of RDX in the $-150-\mathrm{mV}$ tests was also paralleled by the appearance of the aqueous RDX transformation products DNX and TNX (Figure 8). DNX appeared in the $\mathrm{pH} 6$ and 8 treatments with the peak concentration of $0.18 \mathrm{mg} / \mathrm{L}$ appearing in the $\mathrm{pH} 6$ reactors $24 \mathrm{hr}$ after addition of RDX. TNX appeared in the $\mathrm{pH} 6$ and 7 tests. The peak solution concentration of $0.045 \mathrm{mg} / \mathrm{L}$ was seen in the $\mathrm{pH} 7$ test 21 days after addition of RDX. DNX and TNX were not detected in solution in the aerobic tests.

Redox potential had a marked effect on RDX recovery. RDX was stable at $+500 \mathrm{mV}$ and least stable at $\mathrm{pH} 6$ in the $-150-\mathrm{mV}$ tests (Table 3 ). These results are similar to those seen in investigations conducted with a surface soil, but much lower recoveries were seen in the anaerobic tests conducted with the surface soil. Only 1.7 percent of the RDX was recovered in these investigations in the $\mathrm{pH} 7$, $-150-\mathrm{mV}$ tests (Table 4) (Price et al. 2001). These results indicate that RDX is stable under oxidizing conditions and is moderately unstable under anaerobic conditions in the low carbon aquifer soil.

\section{Mass balance of $\left[{ }^{14} \mathrm{C}\right] \mathrm{RDX}$}

Most of the radioactivity remained in the aqueous phase of the soil:water slurries (Table 4). Higher mineralization was seen in the anaerobic tests, where 26 percent of radio-labeled carbon was mineralized as $\mathrm{CO}_{2}$. These results differ from those seen in investigations conducted with a surface soil under the same Eh conditions at a $\mathrm{pH}$ of 7 , where 80 percent of the radioactivity was mineralized as $\mathrm{CO}_{2}$ (Table 4).

\section{Cation Substitution}

Of the untreated soils and clays, only untreated montmorillonite possessed a $K_{d}$ comparable to that observed with the homo-ionic $\mathrm{K}^{+}$and $\mathrm{NH}_{4}^{+}$material (Price 


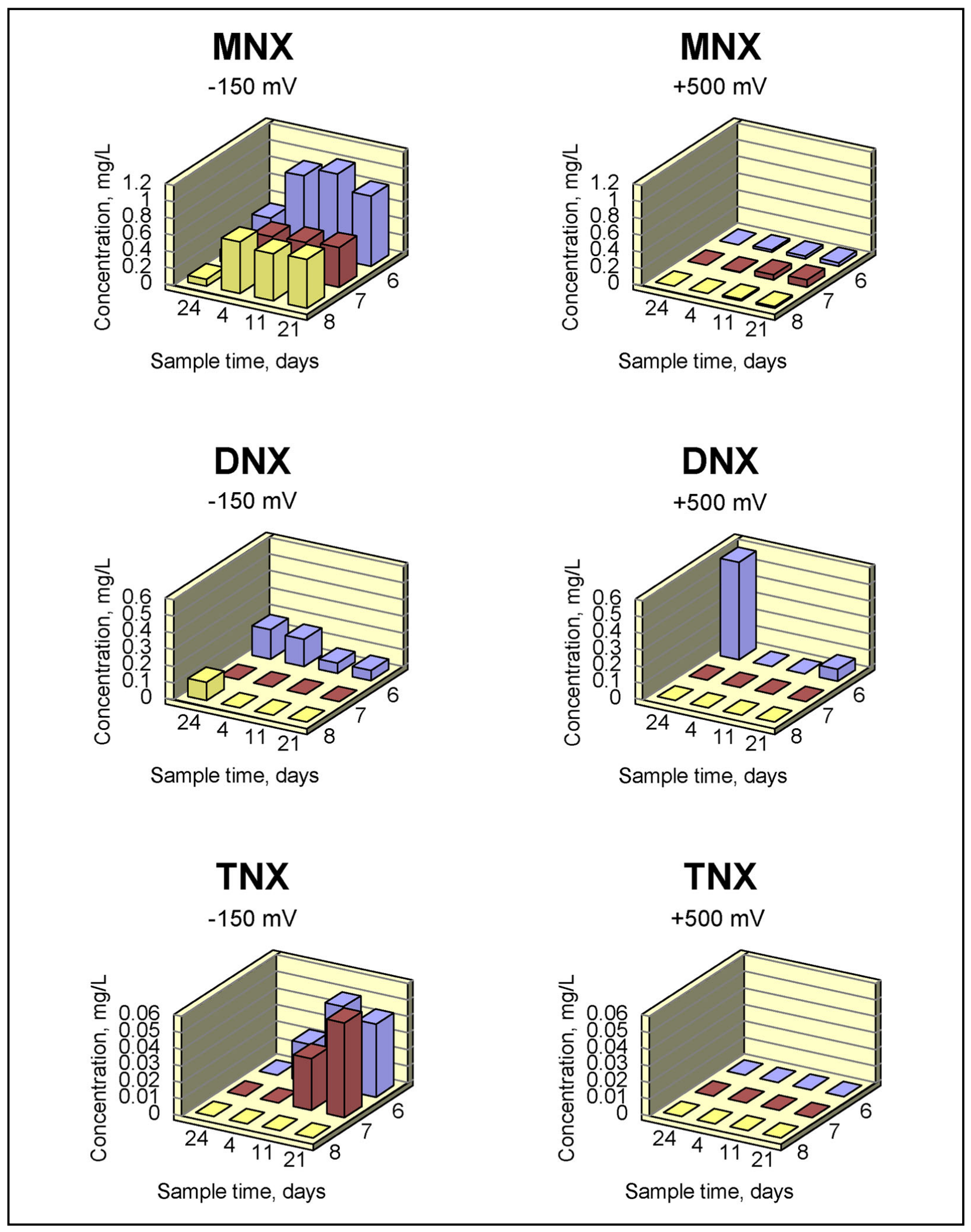

Figure 6. RDX transformation products in solution over time at each Eh and $\mathrm{pH}$ 


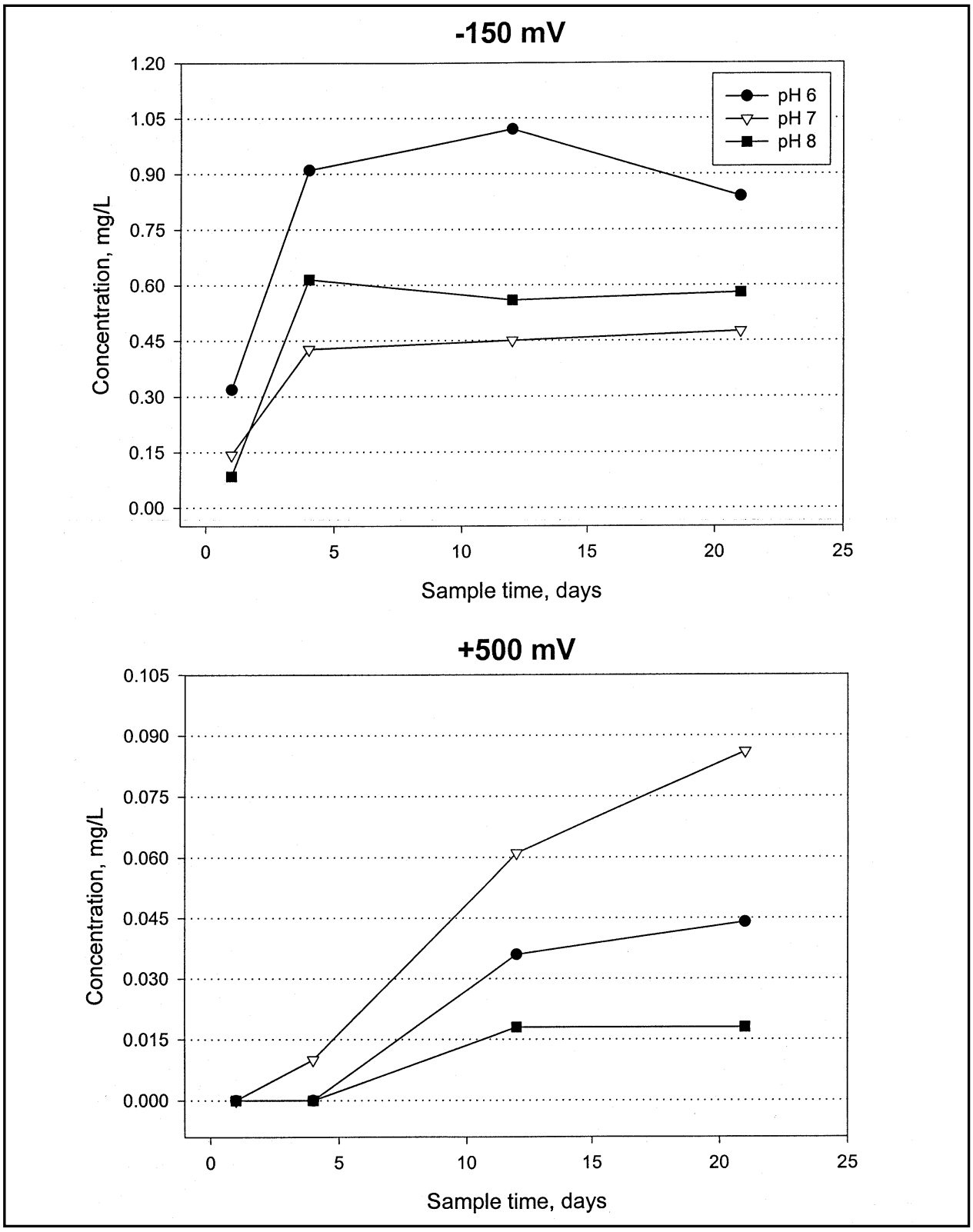

Figure 7. MNX aqueous concentrations over time at each Eh and $\mathrm{pH}$

et al. 2000). Saturation with $\mathrm{K}^{+}$and $\mathrm{NH}_{4}^{+}$did not significantly increase TNT $K_{d}$ above that of untreated montmorillonite. However, $\mathrm{Ca}^{++}$saturation resulted in a $K_{d}$ well below those resulting from $\mathrm{K}^{+}$and $\mathrm{NH}_{4}^{+}$saturation or the untreated montmorillonite. Exchangeable $\mathrm{K}^{+}, \mathrm{NH}_{4}^{+}, \mathrm{Na}^{+}$, and $\mathrm{Ca}^{++}$constituted 97.6 percent of the total cation exchange capacity (CEC) of the montmorillonite, with 9 percent of the exchange sites containing $\mathrm{K}^{+}$and $\mathrm{NH}_{4}^{+}$and the remainder $\mathrm{Ca}^{++}$(87.7 percent) and $\mathrm{Na}^{+}$(3.5 percent). Sorption of TNT on montmorillonite containing 90-percent $\mathrm{Ca}^{++}$and 10 -percent $\mathrm{K}^{+}$produced a $K_{d}$ of $172 \mathrm{~L} / \mathrm{kg}$, well below the unamended $K_{d}$ of $413 \mathrm{~L} / \mathrm{kg}$. These results indicate that the interactions of cations with clay mineral surfaces may be more complex than interactions with aquifer soils. 


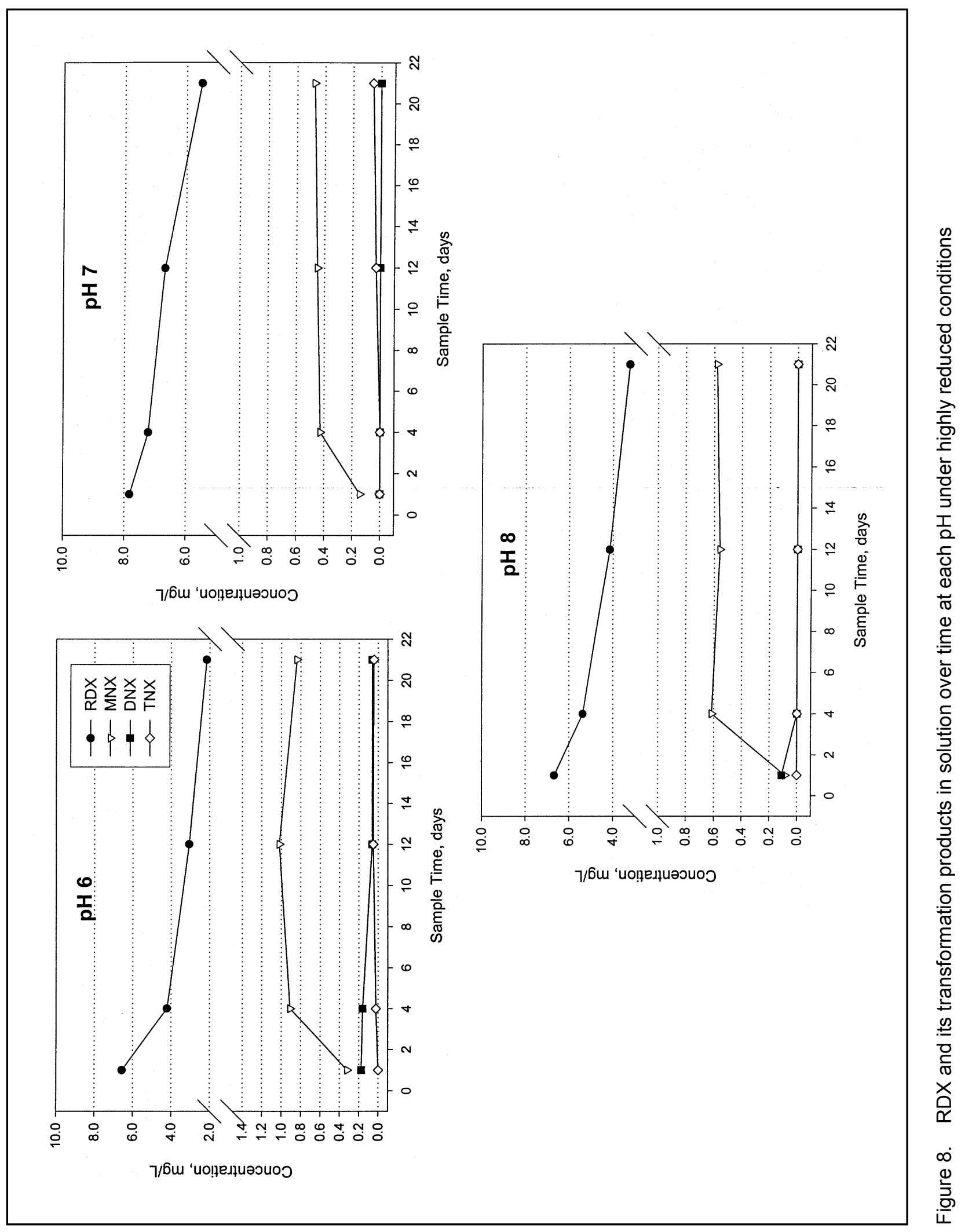




\begin{tabular}{|c|c|c|c|}
\hline \multicolumn{4}{|c|}{$\begin{array}{l}\text { Table } 3 \\
\text { Percent Recovery of RDX (Aqueous Plus Soil Phase) } 21 \text { days After } \\
\text { Addition of } 26 \text { mg RDX }\end{array}$} \\
\hline \multirow[b]{2}{*}{ Treatment } & \multicolumn{3}{|c|}{$\mathrm{pH}$} \\
\hline & 6 & 7 & 8 \\
\hline \multicolumn{4}{|c|}{ Aquifer Soil } \\
\hline$-150 \mathrm{mV}$ & $\overline{277}$ & \begin{tabular}{|l|l|}
61 \\
\end{tabular} & $\begin{array}{l}40 \\
\end{array}$ \\
\hline$+500 \mathrm{mV}$ & 86 & 98 & 100 \\
\hline \multicolumn{4}{|c|}{ Surface Soil } \\
\hline$-150 \mathrm{mV}$ & 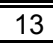 & \begin{tabular}{l|l}
1.7 \\
\end{tabular} & $\bar{~} 6$ \\
\hline$+500 \mathrm{mV}$ & 97 & 75 & 91 \\
\hline
\end{tabular}

\begin{tabular}{|c|c|c|c|}
\hline \multicolumn{4}{|c|}{$\begin{array}{l}\text { Table } 4 \\
\text { Percent Recovery of Radioactivity in Tests Conducted With an } \\
\text { Aquifer Soil and a Surface Soil }\end{array}$} \\
\hline \multirow[b]{2}{*}{ Treatment } & \multicolumn{3}{|c|}{ Phase } \\
\hline & Water & Soil & $\mathrm{CO}_{2}$ \\
\hline \multicolumn{4}{|c|}{ Aquifer Soil } \\
\hline 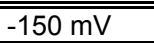 & 85 & 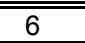 & 26 \\
\hline$+500 \mathrm{mV}$ & 100 & 15.2 & 5.6 \\
\hline \multicolumn{4}{|c|}{ Surface Soil } \\
\hline$-150 \mathrm{mV}$ & 14.3 & 3.2 & 80.1 \\
\hline$+500 \mathrm{mV}$ & 87.8 & 7.03 & 5.4 \\
\hline
\end{tabular}

Specific adsorption of TNT in homo-ionic $\mathrm{K}^{+}$and $\mathrm{NH}_{4}^{+}$aquifer soils and clay minerals was highly correlated with CEC, showing values of $r^{2}=0.976$ and $r^{2}=0.993$, respectively. The strong relationship between TNT adsorption and CEC is not surprising in view of the relationship between CEC and TNT adsorption observed for a wide range of surface and aquifer soils (Brannon et al. 1999). Adsorption of nitroaromatic compounds such as TNT primarily occurs at easily accessible external surfaces of clay minerals (Haderlein, Weissmahr, and Schwarzenbach 1996), which CEC is apparently measuring.

Increasing the concentration of $\mathrm{K}^{+}$in solution decreased concentrations of TNT, indicating increased TNT sorption (Figure 9). Increasing concentrations of a $3: 1 \mathrm{~K}^{+}: \mathrm{Ca}^{++}$mixture resulted in lower sorption and increased solution concentrations of TNT compared to $\mathrm{K}^{+}$alone after $\mathrm{K}^{+}$concentrations exceeded $150 \mathrm{mg} / \mathrm{L}$ (Figure 9). This result is consistent with Weissmahr et al. (1999) who showed that 4-nitrotoluene $K_{d}$ 's in montmorillonite increased in bi-ionic mixtures of $\mathrm{K}^{+}$and $\mathrm{Ca}^{++}$as the equivalent fraction of exchangeable $\mathrm{K}^{+}$increased. However, the curves diverge at a threshold due to increased coverage of the exchange complex by $\mathrm{Ca}^{++}$ at higher solution concentrations. The aquifer soils $K_{d}$ for $\mathrm{Ca}^{++}$was approximately three times that of $\mathrm{K}^{+}$. Therefore, as the concentration of $\mathrm{Ca}^{++}$increased, increased surface coverage by $\mathrm{Ca}^{++}$relative to $\mathrm{K}^{+}$apparently occurred.

This premise was tested by determining $K_{d}$ values of TNT for the same aquifer soil at various equivalent fractions of $\mathrm{K}^{+}$and $\mathrm{Ca}^{++}$. The $K_{d}$ values for biionic $\mathrm{K}^{+}: \mathrm{Ca}^{++}$soils were intermediate to homo-ionic $\mathrm{K}^{+}$and $\mathrm{Ca}^{++}$soils (Figure 10). However, the curves exhibited similar shapes. This is consistent with 


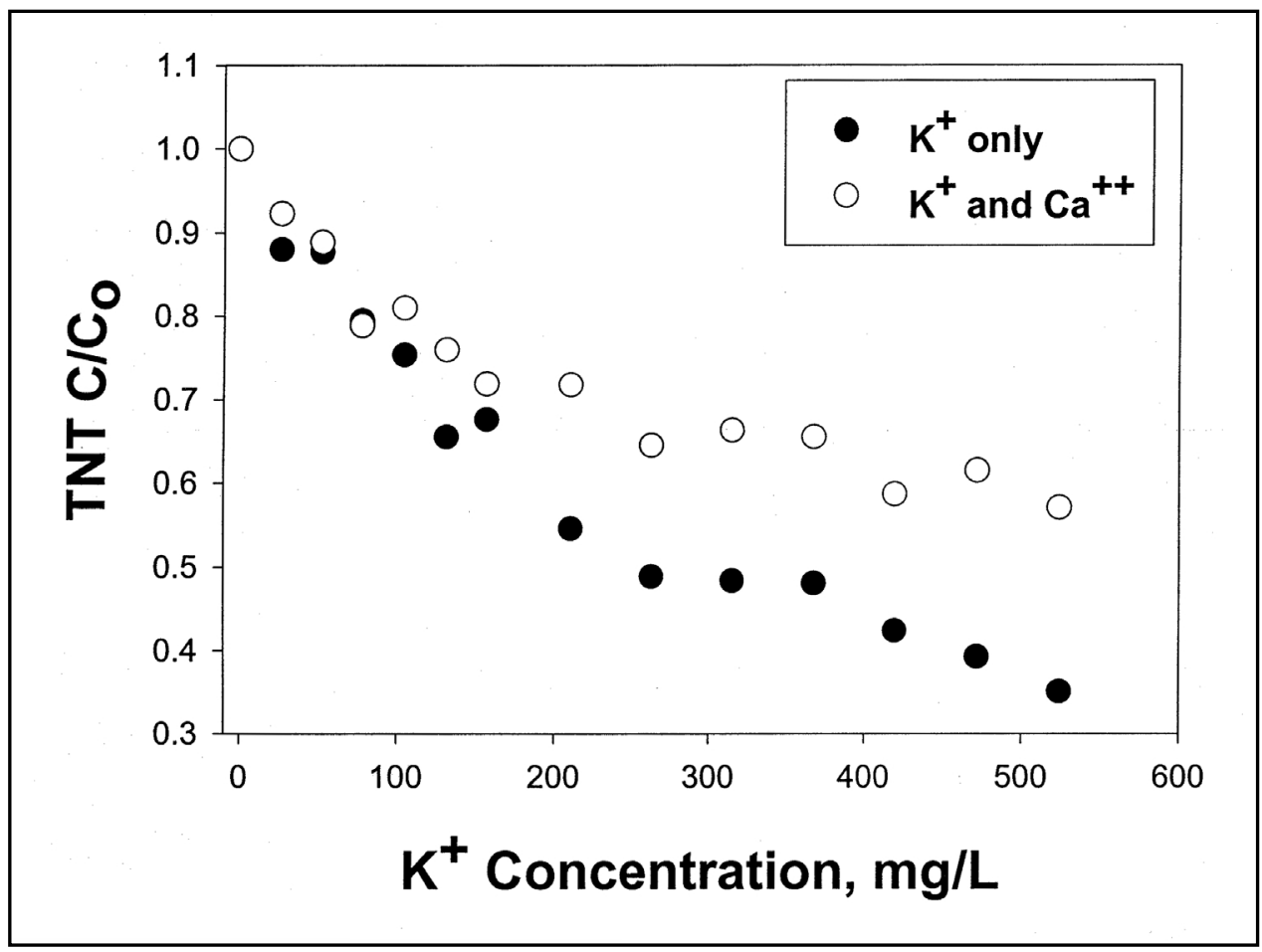

Figure 9. Change in relative TNT concentrations as a function of $\mathrm{K}^{+}$and $\mathrm{Ca}^{++}$ solution concentrations

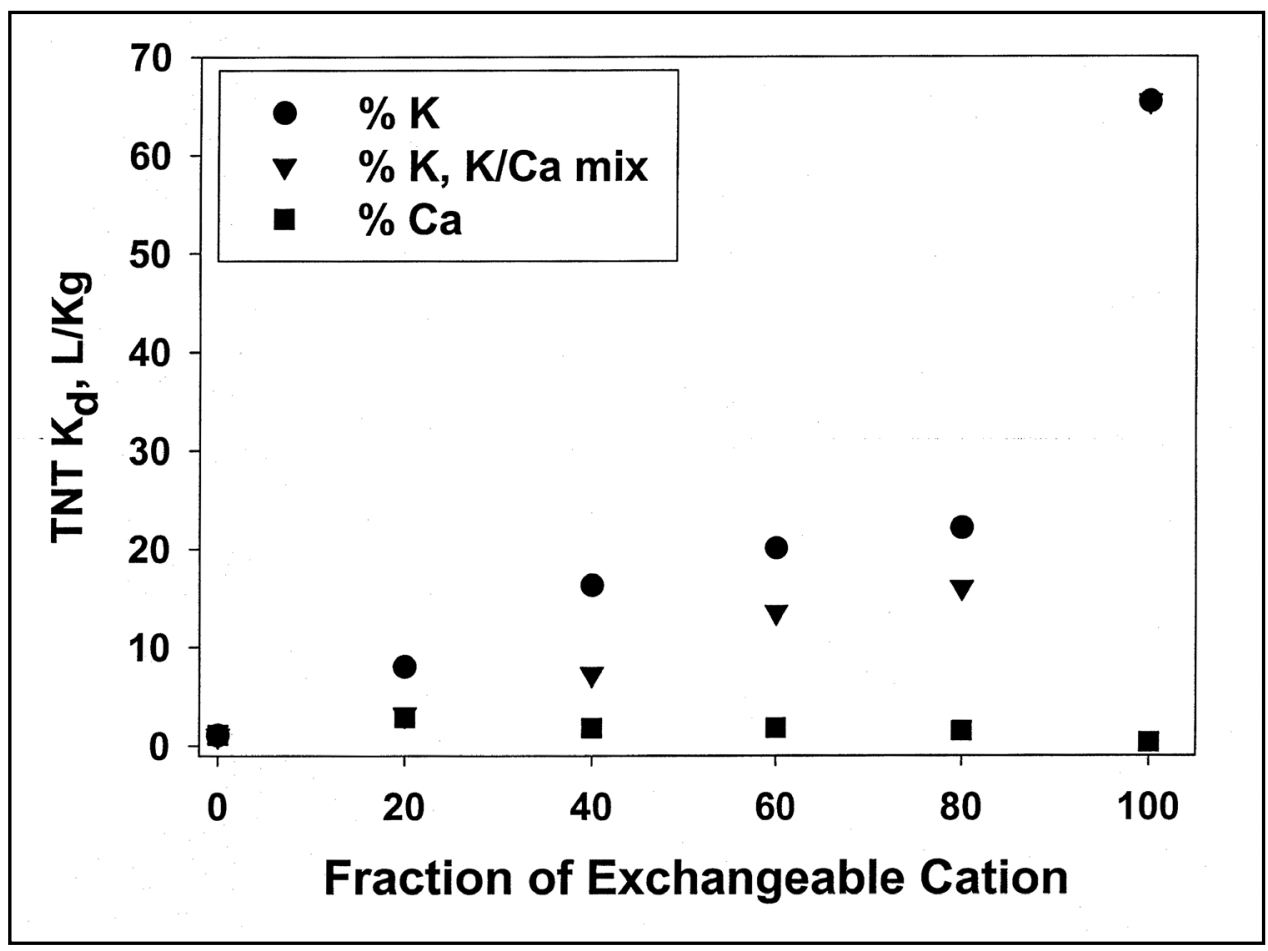

Figure 10. Adsorption of TNT to bi-ionic $\mathrm{K}^{+}: \mathrm{Ca}^{++}$, and homo-ionic $\mathrm{K}^{+}$and $\mathrm{Ca}^{++}$ aquifer soil 
most of the exchange complex being occupied by $\mathrm{Ca}^{++}$(Jackson 1958). The increase in $K_{d}$ with increasing fraction $\mathrm{K}^{+}$was not linear, increasing most steeply up to the point where $\mathrm{K}^{+}$occupied 40 percent of the exchange complex. The increase in $K_{d}$ between 40- and 80-percent coverage of the exchange complex by $\mathrm{K}^{+}$was relatively minor compared to the pronounced increase once homo-ionic $\mathrm{K}^{+}$ coverage of the exchange complex was attained. These results indicate that the greatest impact of $\mathrm{K}^{+}$on increasing sorption of TNT occurs when 100-percent coverage is attained, but that sorption increases substantially up to 40-percent coverage of the exchange complex. Coverage of the exchange complex with between 40 and 80 percent $\mathrm{K}^{+}$yields only small increments of improved sorption. 


\section{Conclusions}

Results of investigations conducted under controlled redox potential and $\mathrm{pH}$ conditions indicated that RDX was relatively stable in solution under aerobic conditions. Highly reducing conditions promoted removal of RDX from solution, particularly at $\mathrm{pH}$ 6. RDX persistence was highest under oxidizing conditions and under anaerobic conditions at $\mathrm{pH}$ 7. Anaerobic conditions promoted increased transformation of RDX to MNX, DNX, and TNX. The $\mathrm{pH}$ affected the disappearance of RDX in the anaerobic systems, with increased removal of RDX from solution observed at $\mathrm{pH} 6$ and 8 compared with $\mathrm{pH} 7$.

Radioactivity recovered in the $\left[{ }^{14} \mathrm{C}\right] \mathrm{RDX}$ mass balance tests was found primarily in the aqueous phase following 21 days incubation under both oxidized and reduced conditions. This distribution was similar to that observed in other investigations conducted with a surface soil, with the exception that in the surface soil tests, most of the radio-label was mineralized under anaerobic, $\mathrm{pH} 7$ conditions.

These results indicate that RDX in an aquifer soil (in the presence of an added energy source) moving into an area of intense reduction will not persist long, even at the lowest rate observed at $\mathrm{pH} 7$. RDX moving into an oxidizing environment will be relatively stable from $\mathrm{pH} 6$ to 8 . Typical aquifer $\mathrm{pH}$ values in the United States range from 6 to 8.5 (Driscoll 1987).

Results of batch shake tests showed that groundwater cation composition strongly affected the sorption of TNT in aquifer soils. TNT adsorption by bi-ionic $\mathrm{K}^{+}: \mathrm{Ca}^{++}$aquifer soil increased until 40-percent coverage of the exchange complex was attained. Past this point, pronounced increases in adsorption were not observed until 100-percent saturation with $\mathrm{K}^{+}$was reached. This indicates that increases in TNT sorption by aquifer soils as a consequence of cation saturation is most pronounced at 100-percent saturation with $\mathrm{K}^{+}$, but that useful increases in sorption can be attained at saturation levels below 40 percent. 


\section{References}

Brannon, J. M. (1983). "The transformation, fixation, and mobilization of arsenic and antimony in contaminated sediments," Ph.D. diss., Louisiana State University, Baton Rouge, LA.

Brannon, J. M., Deliman, P., Ruiz, C., Price, C., Qasim, M., Gerald, J. A., and Yost, S. (1999). "Conceptual model and process descriptor formulations for fate and transport of UXO," Technical Report IRRP-99-1, U.S. Army Engineer Waterways Experiment Station, Vicksburg, MS.

Cattaneo, M. V., Pennington, J. C., Brannon, J. M., Gunnison, D., Harrelson, D. W., and Zakikhani, M. (2000). "Natural attenuation of explosives," Remediation of hazardous waste contaminated soils. Marcel Dekker, Inc., New York.

Crawford, R. L. (1995). "Biodegradation of nitrated munition compound and herbicides by obligately anaerobic bacteria." Biodegradation of nitroaromatic compounds. J. C. Spain, ed., Plenum, New York.

Driscoll, F. G. (1987). Groundwater and wells. 2nd ed., Johnson Divisions, St. Paul, MN.

Haderlein, S. B., and Schwarzenbach, R. P. (1993). "Adsorption of substituted nitrobenzenes and nitrophenols to mineral surfaces," Environ. Sci. Technol. 27, 316-326.

Haderlein, S. B., Weissmahr, K. W., and Schwarzenbach, R. P. (1996). "Specific adsorption of nitroaromatic explosives and pesticides to clay minerals," Environ. Sci. Technol. 30, 612-622.

Jackson, M. L. (1958). Soil chemical analysis. Prentice-Hall, Englewood Cliffs, NJ.

McCormick, N. G., Cornell, J. H., and Kaplan, A. M. (1984). "The fate of hexahydro-1,3,5-trinitro-1,3,5-triazine (RDX) and related compounds in anaerobic denitrifying continuous culture systems using simulated wastewater," DRX-AS-CR-82155, U.S. Army Toxic and Hazardous Materials Agency, Aberdeen Proving Ground, Aberdeen, MD. 
Myers, T. E., Brannon, J. M., Pennington, J. C, Townsend, D. M., Davis, W. M., Ochman, M. K., Hayes, C. A., and Myers, K. F. (1998). "Laboratory studies of soil sorption/transformation of TNT, RDX, and HMX," Technical Report IRRP-98-8, U.S. Army Engineer Waterways Experiment Station, Vicksburg, MS.

Patrick, W. H., Jr., Williams, B. G., and Moraghan, J. T. (1973). "A simple system for controlling redox potential and $\mathrm{pH}$ in soil suspensions," Soil Science Soc. Am. Proc. 37, 331-332.

Pennington, J. C., and Brannon, J. M. (In Press). "Environmental fate of explosives," Thermo Chemica Acta.

Pennington, J. C., and Patrick, W. H., Jr. (1990). "Adsorption and desorption of 2,4,6-trinitrotoluene by soils," J. Environ. Qual. 19, 559-567.

Pennington, J. C., Gunnison, D., Brannon, J. M., Harrelson, D. W., Zakikhani, M., McGrath, C. J., Frederickson, H., May, J., Myers, T. E., Clarke, J., Reynolds, M., Jenkins, T., Miyares, P. H., Coffin, R. B., Perkins, E., Hayes, C., Felt, D., Ringelberg, D., and Townsend, D. M. (1999). "Natural attenuation of explosives in soil and water systems at DoD sites: Interim report," Technical Report EL-99-8, U.S. Army Engineer Waterways Experiment Station, Vicksburg, MS.

Price, C. B., Brannon, J. M., and Hayes, C. (1997). "Effect of redox potential and pH on TNT transformation in soil-water slurries," J. Environ. Eng. 123, 988992.

Price, C. B., Brannon, J. M., and Yost, S. L. (1998). "Transformation of RDX and HMX under controlled Eh/pH conditions," Technical Report IRRP-98-2, U.S. Army Engineer Waterways Experiment Station, Vicksburg, MS.

Price, C. B., Brannon, J. M., Yost, S. L., and Hayes, C. A. (2000). "Adsorption and transformation of explosives in low-carbon aquifer soils," Technical Report ERDC/EL TR-00-11, U.S. Army Engineer Research and Development Center, Vicksburg, MS. . (2001). "Relationship between redox potential and pH on RDX transformation in soil-water slurries," J. Environ. Eng. 127, 26-31.

Pugh, D. L. (1982). "Milan Army Ammunition Plant contamination survey," DRXTH-FR-8213, U.S. Army Toxic and Hazardous Materials Agency, Aberdeen Proving Ground, Aberdeen, MD.

Sikka, H. C., Banerjee, S., Pack, E. J., and Appleton, H. T. (1980). "Environmental fate of RDX and TNT," Technical Report 81-538, U.S. Army Medical Research and Development Command, Fort Detrick, Frederick, MD.

Spalding, Roy F., and Fulton, John W. (1988). "Groundwater munition residues and nitrate near Grand Island, Nebraska, U.S.A.," J. Contam. Hydrol. 2, 139153. 
Spanggord, R. J., Mill, T., Chou, T., Mabey, W. R., Smith, J. H., and Shonh, L. (1980). "Environmental fate studies on certain munition wastewater constituents - Final Report, Phase II - Laboratory studies," Technical Report Project No. LSU 7934, Defense Technical Information Center, Alexandria, VA.

U.S. Environmental Protection Agency (1994). Test methods for evaluating solid waste, physical/chemical methods $S W$-846. 3rd ed., Update II, Washington DC.

Weissmahr, K. W., Haderlein, S. B., and Schwarzenbach, R. P. (1998). "Complex formation of soil minerals with nitroaromatic explosives and other $\pi$ acceptors," Environ. Sci. Technol. 27, 316-326.

Weissmahr, K. W., Hildenbrand, M., Schwarzenbach, R. P., and Haderlein, S. B. (1999). "Laboratory and field scale evaluation of geochemical controls on groundwater transport of nitroaromatic ammunition residues," Environ. Sci. Technol. 33, 2593-2600. 


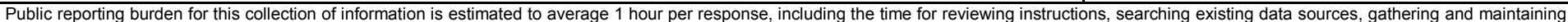

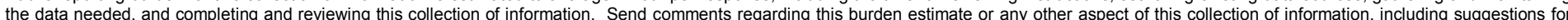

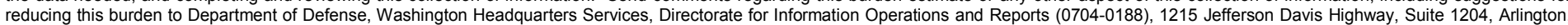

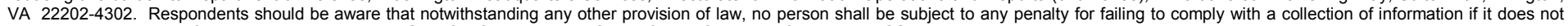
display a currently valid OMB control number. PLEASE DO NOT RETURN YOUR FORM TO THE ABOVE ADDRESS.
1. REPORT DATE (DD-MM-YYYY)
August 2001

4. TITLE AND SUBTITLE

Adsorption and Transformation of RDX in Low-Carbon Aquifer Soils
3. DATES COVERED (From - To)

5a. CONTRACT NUMBER

5b. GRANT NUMBER

5c. PROGRAM ELEMENT NUMBER

5d. PROJECT NUMBER

5e. TASK NUMBER

5f. WORK UNIT NUMBER

8. PERFORMING ORGANIZATION REPORT NUMBER

ERDC/EL TR-01-19

U.S. Army Engineer Research and Development Center

Environmental Laboratory

3909 Halls Ferry Road

Vicksburg, MS 39180-6199

9. SPONSORING / MONITORING AGENCY NAME(S) AND ADDRESS(ES)

10. SPONSOR/MONITOR'S ACRONYM(S)

U.S. Army Corps of Engineers

Washington, DC 20314-1000
11. SPONSOR/MONITOR'S REPORT NUMBER(S)

\section{DISTRIBUTION / AVAILABILITY STATEMENT}

Approved for public release; distribution is unlimited.

\section{SUPPLEMENTARY NOTES}

\section{ABSTRACT}

Disposal operations from the manufacturing process of the explosives 2,4,6-trinitrotoluene (TNT), 1,3,5-trinitro-1,3,5hexahydrotriazine (RDX), and octahydro-1,3,5,7-tetranitro-1,3,5,7-tetrazocine (HMX) have resulted in the contamination of soil and groundwater at many active and inactive munitions sites. Natural attenuation of these compounds is one option for addressing site cleanup. The potential for this option to be successful in low-carbon aquifer soils is dependant upon the ability of these soils to adsorb and transform explosives. Therefore, an understanding of the processes that control the mobility and transformation of explosives in these types of soils is needed to evaluate the processes of natural attenuation in aquifers.

The objective of these studies was to investigate environmental conditions such as redox potential, $\mathrm{pH}$, and groundwater quality on sorption and transformation of explosives in low-carbon aquifer soils.

Laboratory investigations addressing the effects of redox potential and pH on RDX transformation in an aquifer soil were conducted by testing at two different redox potentials and three $\mathrm{pH}$ levels. An 18:1 (water:soil) suspension spiked with $15 \mathrm{mg}$ RDX was used. Results indicate that RDX added to a low-carbon soil was relatively stable under aerobic conditions. Highly reducing conditions promoted removal of RDX from solution, and increased transformation was seen.

(Continued)

\begin{tabular}{|ll}
\hline 15. SUBJECT TERMS & Groundwater \\
Aquifer soil & $\mathrm{pH}$ \\
Cation substitution & RDX sorption \\
\hline 16. SECURITY
\end{tabular}

16. SECURITY CLASSIFICATION OF:

a. REPORT

UNCLASSIFIED

b. ABSTRACT
UNCLASSIFIED

c. THIS PAGE

UNCLASSIFIED
Redox potential

TNT adsorption

\begin{tabular}{l|c|}
\hline $\begin{array}{l}\text { 17. LIMITATION } \\
\text { OF ABSTRACT }\end{array}$ & $\begin{array}{c}\text { 18. NUMBER } \\
\text { OF PAGES }\end{array}$ \\
& 27 \\
&
\end{tabular}

19a. NAME OF RESPONSIBLE PERSON

19b. TELEPHONE NUMBER (include area code) 


\section{4. (Concluded)}

Studies addressing various degrees of cation substitution on adsorption of TNT in an aquifer soil and two clay minerals were conducted. Results of batch shake tests showed that groundwater cation composition strongly

affected TNT sorption by aquifer soils. TNT sorption was most pronounced at 100 -percent saturation with $\mathrm{K}^{+}$, but results showed that increases in sorption could be attained at saturation levels below 40 percent. 